Paper published in the Journal Poverty \& Public Policy, 2019

The publication is available at: https://doi.org/10.1002/pop4.243

To cite this article: Gibrán Cruz-Martínez (2019): Older-Age Social Pensions and Poverty: Revisiting Assumptions on Targeting and Universalism, Poverty \& Public Policy, Volume 11, Issue 1-2, pp. 31-56. https://doi.org/10.1002/pop4.243

\title{
Older-Age Social Pensions and Poverty: Revisiting Assumptions on Targeting and Universalism
}

\author{
Gibrán Cruz-Martínez \\ Institute of Public Goods and Policies, CSIC \\ gibran.cruz@csic.es
}

\begin{abstract}
:
Whether social protection benefits should be assigned to all (universal) or kept only for those who meet specific criteria (targeting) remains one of the most contentious questions in social policy research. The purpose of this article is to revisit three assumptions on the two main social policy options for the provision of social benefits to older persons. Each assumption is assessed through counterfactual reasoning using a combination of literature review and statistical analysis with a global perspective. The study finds that (i) 79 countries would be economically able to shift from targeted noncontributory pensions to basic universal non-contributory pensions with less than 1.2 percent of the respective national gross domestic products; (ii) 16 countries have meanstested/regional-tested non-contributory pensions more expensive than a hypothetical basic universal social pension; (iii) An arbitrary threshold of "economic development" is not a limitation for implementing social pensions. (iv) At least, 17 countries with relatively low economic development have successfully implemented social pensions without means-targeting. Therefore, contrary to what several international organisations and scholars have argued, universal social pensions are politically and economically viable and efficient strategies to alleviate income poverty.
\end{abstract}

Keywords: social protection, social policy, development, social assistance, cash transfers 


\section{INTRODUCTION}

What are the possibilities for low and middle-income countries when implementing and extending social policy programmes for the older population? There are two broad available options on the social policy menu: social insurance and social assistance. The former one is financed through contributions, with benefits derived from work, and centred on redistribution throughout the life cycle of the workers (Bismarckian approach); or financed through taxes, with flat-rate benefits, and centred on poverty reduction (Beveridgean approach). On the other hand, social assistance programmes are generally non-contributory programmes using benefits to level up individuals living below a minimum societal standard. In reality, countries use a mix of policy options and the approaches may vary between welfare areas (e.g. health, pensions, and education).

The expansion of social insurance in the less developed world remains a challenge due to low participation rates in the formal economy and the under-institutionalised regressive taxation system, among others (Bastagli, 2013; Cruz-Martinez, 2015). Following the World Bank (1994) recommendations, social assistance pensions should be considered as a "first pillar" of social protection. Social assistance programs can be used as a tool to promote social development ${ }^{1}$ in all countries, reducing social exclusion, poverty ${ }^{2}$ and inequality.

Social protection started to be recognised recently as a social development practice/strategy, involving communities, the third sector, individuals and alternative welfare providers in the development process. The objective of social development is moving beyond the narrow view of social assistance/insurance as income-maintenance programmes, towards a vision of the social protection system as an incubator of socioeconomic development, ${ }^{3}$ economic stability and capabilities formation (Midgley, 2014, pp. 174-178).

According to Mulligan and Sala-i-Martin (1999) the theory of the public pension systems is based on the idea that markets fail to provide a minimum standard of living for the older population; thus the government have to intervene to create guarantees through pensions. Income poverty alleviation is not necessarily the primary function of contributory pensions in high-income countries. On the contrary, its primary purpose is

on consumption smoothing ${ }^{4}$ and redistribution between high and low-income individuals,

\footnotetext{
${ }^{1}$ Social development is defined by Midgley (2014, p. 13) as "a process of planned social change designed to promote the well-being of the population as a whole within the context of a dynamic, multifaceted development process".

${ }^{2}$ The World Development Report showcased social protection as a critical ingredient in poverty alleviation (World Bank, 2001).

${ }^{3}$ The fact of having an institutionalized social protection system is one of the reasons for highincome countries socio-economic development (Freeland, 2013, pp. 2-3).

${ }^{4}$ Consumption smoothing refers to "a process which enables a person to transfer consumption from her productive middle years to her retired years, allowing her to choose her preferred time path of consumption overworking and retired life" Barr and Diamond (2006, p. 16). See Barr (2012) for more details on the rationale behind consumption smoothing.
} 
men and women, as well as between individuals in urban and rural areas. Whether social protection benefits should be assigned to all (universal) or kept only for those who meet specific criteria (targeting) remains one of the most contentious questions in social policy research.

The purpose of this paper is to revisit three assumptions on the two main social policy options for the provision of social benefits to older persons.

- Assumption 1: 'Poor' countries should wait to cross the threshold of 'economic development' before implementing universal pensions.

- Assumption 2: Means-tested targeting is more efficient than universal social provision allocating resources in a time of budget constraints and globalisation. ${ }^{5}$

- Assumption 3: With an under-developed taxation system there is no alternative than to target the income poor to alleviate monetary deprivations.

Each assumption is assessed through counterfactual reasoning using a combination of literature review and statistical analysis with a global perspective. The paper is organised as follows. Section 2 provides the conceptual background, featuring a discussion on universalism and targeting as social policy options, life-cycle risks and the conceptualisation of poverty. The historical context of universalism versus targeting as regards poverty alleviation is addressed in Section 3. Section 4 re-examines the three assumptions and elaborates on the issues addressed. Section 5 provides conclusions and points for further research.

\section{CONCEPTUAL BACKGROUND}

What are the two main social policy options for the provision of social benefits to those in the later periods of their lives?

Universalism and targeting (selectivity) have been the two core principles underlying social provision. Under universalism, all are entitled to benefit from social policy programs. Thus, following Marshall (1950), under universalism, every individual experience social provision as a social-citizen right. Universalism is also the foundation of the social democratic model of welfare system (i.e., universalistic / Nordic variety). High-income countries that follow this model have developed a generous social security system embedded within the public sector with high-quality social insurance programs (pensions, unemployment, healthcare). Also, social policy plays an instrumental role in ensuring minimum living standards guaranteed to all individuals under the overall objective of achieving greater social equality.

On the other hand, under targeting, only individuals who meet specific criteria are eligible to receive benefits. Targeted programs provide social assistance to selected individuals only after confirming eligibility and accepting an individual as a 'truedeserver'. Means-tested targeting is the foundation of the liberal or residual welfare state

${ }^{5}$ Efficiency is understood as the best performance possible with the least waste of resources. 
model. ${ }^{6}$ Rather than creating a basic universal social protection floor, residual welfare models guarantee a targeted social protection floor for those considered as 'incapable' to satisfy their social risks by their own means through the market (Cruz-Martinez, 2015; Sánchez de Dios, 1993). High-income countries that follow the residual model have developed social security programs where the limits of social protection equal the marginal propensity to opt for the social assistance programs instead of working (poverty trap) (Deacon \& Bradshaw, 1983; Esping-Andersen, 1990). Coverage is determined mainly by the purchasing power of the population, i.e. individuals with more economic deprivations are the primary recipients of the scarce and limited benefits (Mishra, 1977).

In contrast to universalism, targeting implies a range of techniques to identify those considered as the neediest and 'deserving poor'. Gilbert (2000, pp. 9-11) identified three 'pure' types of targeting: targeting by category, targeting by means and targeting by needs. In reality, targeted social protection programs may function with a combination of any of these. Targeting by category use 'categories' as proxies to identify a group of the population with needs. Categories include a range of criteria such as age, employment status, family type, disability status, marital status, family size, and geographical location. Beneficiaries of programs using targeting by categories receive a universal flat-rate benefit (e.g. universal pensions for the aged, disabled, single-parent families) unless other types of targeting are used in conjunction (e.g. targeting by means).

As the name suggests, targeting by means involves means testing. Generally, individuals are tested for incomes, assets or employment to determine their eligibility for social assistance. Food assistance, public housing and income support are among the diverse types of means-tested benefits, commonly known as social assistance programs.

Beneficiaries of programs using targeting by means may receive a flat-rate benefit or service (e.g. public health-care) although generally, they receive an incremental benefit depending on the degree of need.

The third type of targeting is similar to targeting by means in that individuals need to be tested before becoming beneficiaries. Targeting by needs requires an additional level of process, assessing the particular circumstances of claimants beyond their income (e.g. housing costs, health status). This targeting approach is generally used in combination with means testing to configure the level of benefits that particular individuals would receive according to their level of need. As such, one may consider this as targeting the targeted.

\section{Universal targeting approach and life-cycle risks}

Since the centenary work of Rowntree (1901), scholars have confirmed -and reconfirmed- that poverty is mainly concentrated at two stages of the life cycle:

\footnotetext{
${ }^{6}$ See Esping-Andersen (1990) for a thorough exposition of the welfare state models. In brief, a liberal or residual model guarantees the minimum of welfare required for the correct functioning of the market; a corporatist model provides welfare via social security in search of social justice; and the universalist or social democratic model combines a fuller set of social protection and labour policies in search of equity (See Del Pino \& Rubio Lara, 2016).
} 
childhood and older-age. Poor children and older persons suffer from multiple deprivations originated by multiple causes. Older-age poverty could be considered as the accumulation of non-random disadvantages while early childhood poverty could be attributed to random disadvantages. A child is randomly born into a family with certain amounts of deprivations, while an older person accumulates disadvantages across her/his life. Therefore, in order to alleviate specific disadvantages and deprivations, these differences should be taken into consideration.

Life-cycle social risks for the children and older persons have been generally allocated to the family and the community. Because of the limited scope of the state and the limited proportion of the population with access to private welfare programs in low and middle income countries, the family have been, historically, at the forefront of satisfying social risks and providing welfare through intergenerational care ${ }^{7}$ (Esping-Andersen, 1999). The institutionalisation of the "welfare state" in OECD countries led to the reassessing of the structural social risks and the welfare relations between the state and society through a new social contract. Social policy was one of the ways in which the state started to ensure the wellbeing of the population by satisfying their social risks.

Outside OECD states, one finds regions with emerging welfare states (e.g. Latin America and East Asia) ${ }^{8}$ however, large segments of the populations living in low and middleincome countries remain without access to social protection as an entitled citizen right. According to the ILO, more than $70 \%$ of the world's population is inadequately covered by social protection. In other words, "only $27 \%$ of the global population enjoys access to comprehensive social security"(ILO, 2014b). This begs the question of why we should heed these figures, which in turn poses the question: why is social protection so important? There is a simple answer, even if the process is less so agreed upon: "Social protection is a key policy tool to reduce poverty and inequality while stimulating inclusive growth by boosting the health and capacity of vulnerable segments of society, increasing their productivity, supporting domestic demand and facilitating the structural transformation of national economies" (ILO, 2014a).

In addition to looking at the coverage of beneficiaries, it is vital to examine the coverage of the transfer. A. Fiszbein, Kanbur, and Yemtsov (2013) show the variation across regions concerning the transfer coverage, measured as the percentage of the income/consumption provided by the social protection programs. Social protection programs in Eastern Europe and Central Asia provide transfers around 53\% of income/consumption of beneficiaries, while for countries in Latin America is halved to $27 \%$ of the income/consumption of beneficiaries. "The lowest level of transfers (less than $10 \%$ ) regionally is found in South Asia and the Middle East and Northern Africa" (Ariel Fiszbein, Kanbur, \& Yemtsov, 2014, p. 168).

\footnotetext{
${ }^{7}$ Refers to the provision of welfare and satisfaction of social risks by family members - mainly women - of so-called dependent population. Reciprocity is the core value behind intergenerational care, which is imbricated in South-European welfare states.

${ }^{8}$ See Cruz-Martinez (2017, 2016); Goodman, White, and Kwon (1998); Huber and Niedzwiecki (2015); Kwon, Mkandawire, and Palme (2009) among others.
} 
While means-tested programs are claimed to have lower costs than universal approaches, they typically deliver sub-optimal benefits (Sen, 1995). Implementing 'universal targeting' programs is one way to solve the sub-optimal benefit limitation. In other words, targeting by category (children, older population) with universal benefits. For example, providing universal child-care and preschool programs, ${ }^{9}$ universal pre- and post-natal care ${ }^{10}$ universal school meals ${ }^{11}$; all three social provisions target children with universal flat-rate benefits/services.

Universal non-contributory pension programs (also known as social pensions) are a viable option to alleviate life-cycle social risks of older-age persons. This is another example of universal targeting, targeting by category (older-age) with universal benefits. Universal pensions are available unconditionally to all citizens who meet the age eligibility (and typically some form of residency) criteria; for beneficiaries, this represents an essential source of income. Several countries across all continents have already implemented universal non-contributory pensions for citizens residing in the country, including, but not limited to: ${ }^{12}$

- Americas: Antigua, Bolivia, Guyana, and Suriname

- Africa: Botswana, Mauritius, Namibia, and Seychelles

- Oceania: Cook Islands, Kiribati, Samoa, New Zealand and Timor-Leste

- Asia: Brunei Darussalam and Nepal

- Caucuses: Georgia

- Europe: Kosovo and Netherlands

\section{HISTORICAL CONTEXT OF THE UNIVERSALISM VERSUS TARGETING DEBATE ON INCOME-POVERTY ALLEVIATION}

Over the last decades, there has been an intense debate between scholars and policymakers regarding the best approach to alleviating income poverty via social protection: universalism or targeting. According to Mkandawire (2005), universalistic policies were the preferred choice during the 1960s and 1970s. This endured into the 1980s when the social policy discourse shifted away from universalism to targeting as a more efficient option to reduce poverty. The neoliberal social policy began to flourish

\footnotetext{
${ }^{9}$ See Barnett, Brown, and Shore (2004) for a case study on this proposal in the United States of America.

${ }^{10}$ This social provision aim to tackle infant mortality rates and promote further capability development. According to Heckman (2012), social investment in the early stages of childhood has more significant effects on the formation of capabilities that similar efforts in subsequent stages of life.

${ }^{11}$ The universal provision of school meals may help to reduce malnutrition and stunting. This policy would be considered as universal targeting, if and only, universal access to school is guaranteed to every child. According to Ariel Fiszbein et al. (2014, p. 168), "school feeding programs, recently reviewed by the World Food Program and the World Bank, exist in 78 developing countries in the world and cover 270 million children".

12 (HelpAge International, 2015a; Shen \& Williamson, 2006)
} 
portraying targeting as a better performer in poverty reduction than universalism and with the least investment of economic resources. Following the path-dependence theory ${ }^{13}$ based on historical (neo) institutionalism (Pierson, 2000; Thelen, 1999), the 1980s could be seen as a 'critical juncture' which established a tendency in global social policy for selectivity. This critical juncture set a trajectory that is difficult to reverse and which is reinforced over time. While this may be a well-known issue amongst academics and policy experts, it is less likely to be taken into consideration by the cadre of government officials, let alone the population which these policies affect (Cruz-Martinez, 2019).

Mkandawire (2005, pp. 1-8) proposes six driving forces behind the shift from universalism toward targeting (selectivity), exposing the logic followed by leading international financial institutions which promoted targeting as the best alternative for social provision.

- Ideological shifts: The rise of conservative governments amongst western powers prioritised individual responsibility for social risks. In times of budget constraints and globalisation, efficiency became the primary concern over equity and social justice. Equity could be considered as the situation in which every individual is treated equally and fair. Market failures, the unequal distribution of wealth and income, and the inequality of opportunities in modern societies make necessary the intervention of the state, communities and NGOs to correct these systemic deficiencies and promote equality.

- The fiscal constraint and the quest for efficiency: Following the 1970's oil crisis and the generalised tax reductions on the wealthiest ${ }^{14}$, budgetary constraint was supported by the idea that there was no other alternative. Following the trickledown theory, higher income taxes were cut down with the purpose of generating incentives for the wealthy to invest in the economy, and thus create jobs and income for everyone. On the other hand, social assistance and subsidies were reduced, and minimum wages were frozen with the purpose of "incentivising" the population to work harder. Chang $(2014$, p. 91) consider this a "curious logic" and asks himself, "why do we need to make the rich richer to make them work harder but make the poor poorer for the same purpose?" The next sentence could explain the logic followed by supporters of targeting in line with the search for efficiency: "in face of limited fiscal resources, it is better to target the resources to the deserving poor" (Mkandawire, 2005, p. 2).

- Shifts in aid: Low and middle-income countries -specifically the aid-dependentwere conditioned by social policy preferences from donor countries and international financial institutions. Consequently, the shift in the ideological foundations of social and economic policies in donor countries/institutions shaped social policy in aid-recipient countries. Funds began to be directed to targeted programs with the aim of creating a safety-net for the most vulnerable as the best way to reach the poor. A safety net is a set of social policies to guarantees a minimum level of welfare in a society. van Oorschot (2002, p. 172) argues that

\footnotetext{
${ }^{13}$, It refers to the causal significance of the preceding stages in a time sequence. Sewell (1996) explains it simply by suggesting that what happens initially in time may affect the possible outcomes of a sequence of events occurring in a subsequent point in time.

${ }^{14}$ Supported by trickle-down economics.
} 
the World Bank and the International Monetary Fund (IMF) tended "to link to their financial loans recommendations and even conditions concerning restricted welfare policies and free-market based economic policies".

- Crisis of universalism: Criticisms began to emerge in reaction to 'artificial' universalism which failed to reach the population on a universal basis. In practice, countries which proclaimed universal provision usually presented, in fact, a 'stratified universalism'. This protected specific social groups (e.g. public servants, military) while a large sector of the population, mainly working in the agriculture and the informal sector became increasingly marginalised. This marginalised sector of income-poor workers lacerated the political support for universalism, and since the 1980s (i.e. neoliberal era) became one of the primary beneficiary groups of means-tested social programmes.

- Exit redistribution: Means-tested targeting was portrayed as a more redistributive option than universal provision, mainly because of the acclaimed higher 'redistributive effect' of targeted transfers to the income poor. However, as Rothstein $(1998,2001)$ among others has confirmed, while targeted programmes may have higher redistributive impacts on income poverty "per unit of money", other factors ${ }^{15}$ make universal programmes more redistributive (Korpi \& Palme, 1998). This is one reason why countries with universal welfare systems (e.g. Nordic countries) exhibit notably less inequality than those who favour meanstested social policy.

- The marginal role of social policy: Social policy was increasingly depicted as a 'last resource' instrument to correct negative outcomes of structural adjustments economic policies, such as poverty. In Latin America, for example, these policies began to be used as a way to reduce the 'undesired' macroeconomic imbalances which occurred in the eighties, the so-called lost decade (Sojo, 2009). Targeting social provision by means, a reflection of the residual welfare regime model became the way forward in poverty alleviation through social policy.

The driving forces discussed in this section started to be used as arguments to steer national and international actors towards selectivity. In the last three decades, scholars and international financial institutions have manufactured assumptions in support of the residual approach to social policy provision. Neoliberal ideology guided policymakers and international funders in the construction of targeted and conditional social policy for the neoliberal era. Next section takes some of the driving forces mentioned in this section to analyse and re-examine three assumptions of targeting social protection.

15 'Other factors' refer mainly to the coalition formation between the working class and the middle class in support for continued welfare state policies benefiting all (Korpi \& Palme, 1998). On the other hand, targeted policies on residual welfare regimes create coalitions between the better-off workers and the middle class against the most deprived sectors of the working population. Therefore, political support for redistribution is more favourable on a universalistic regime. 


\title{
RE-EXAMINING SOME OF THE ASSUMPTIONS OF TARGETING SOCIAL PROVISION
}

\author{
Assumption 1: 'Poor' countries should wait to cross the threshold of 'economic \\ development' before implementing universal pensions
}

Based on the logic of industrialism and Wagner's Law, a selection of social policy scholarship has forwarded the idea that a certain degree of economic development is requisite in order to develop an institutionalised social protection system. This literature states that surpluses generated by the process of industrialisation facilitates the economic viability of the development of social security programmes, while the destruction of preindustrial modes of social reproduction facilitates its political support by the workforce (Esping-Andersen, 1990; Scarbrough, 2000). There is evidence showing that economic growth is essential for the economic viability of social protection schemes (Barr \& Diamond, 2006; Clark, Munnell, \& Orszag, 2006), however progressive ${ }^{16}$ fiscal reforms and the incorporation (i.e., formalisation) of the population working in the 'informal sector $^{17}$ - specifically in the case of low and middle-income countries - may reduce this economic growth requisite.

The incorporation of progressive tax systems and the formalisation of the working population would be effective reforms for increasing public revenues and to facilitate comprehensive social policy reforms (Cruz-Martinez, 2018). The question, which naturally emerges, is whether it is decidedly necessary for 'less-developed' countries to wait until they surpass an arbitrary economic performance threshold in order to have the economic capacity for implementing universal welfare programmes (e.g. noncontributory pensions)?

In order to test this assumption, this section explores the historical experience of Nordic countries which are argued to stand out as the models of universal welfare policies. Between the late 1940s and 1960s, Nordic countries abolished means-tested targeting in their 'basic security' pensions. These basic security pensions are basic social pensions, equal for all individuals. Sweden led the Nordic countries, creating the 'People's Pension' in 1946, a universal pension benefiting all individuals above the retirement age (Elmer, 1960). Similar basic security pension programs were created in Finland (1956), Norway (1957) and Denmark (1960) (US Social Security Administration, 2015). According to Carroll and Palme (2006, p. 19), the basic universal pensions had the effect of "creating the broadest possible political base for combating poverty among the elderly", as all individuals above the retirement-age became beneficiaries while the

\footnotetext{
${ }^{16}$ According to Gugushvili and Hirsch $(2014$, p.2) progressivity refers to "the extent to which a tax and benefit system redistributes from upper to lower income groups. Unlike the size of the redistributive budget, this takes account of which groups are its net beneficiaries". The opposite is a regressive system.

${ }^{17}$ Refers to the population with a salaried job whose accrued wages are not reported to the national tax agency, therefore does not follow the formally recognise labour laws in a country.
} 
working-age started to acknowledge the eventuality of their own future status of beneficiaries.

By using the average 'economic performance' of four Nordic countries by the time they implemented the first universal basic security pensions as a threshold (8.636,69 USD $\mathrm{PPP})^{18}$, it is possible to test how many countries, in the present, would be in economically viable positions to implement universal social pension programmes. Output-side real gross domestic product (GDP) per capita at chained purchasing power parity (PPP) (in 2005 USD) is used as a proxy to operationalise the 'economic performance' variable. Output-side real GDP per capita allows the comparison of relative productive capacity across countries and over time. Data come from the Penn World Table 8.1 (Feenstra, Inklaar, \& Timmer, 2015).

Using GDP per capita as a proxy of living standards is subjected to many criticisms. First, improvements in GDP per capita might not reflect gains experienced by a significant part of the society, due to unequal distribution of resources and consumption of outputs. Bauman (2014) is just one of the scholars who criticise the use of GDP as an indicator of economic development, economic growth or happiness, mainly because it does not take into account income inequality. Therefore, in this paper GDP per capita is used as a proxy of economic performance. ${ }^{19}$ If the argument that states must first reach an arbitrary threshold of economic development is to be taken seriously, states with higher GDP per capita than the benchmark set by the Nordic average should (hypothetically) have the room to explore this option for their citizens.

Figure 1 illustrates the number of countries with an actual higher level of economic performance than Nordic countries had by the time they implemented their first basic universal pensions. Out of 162 countries with available data, $81(50 \%)$ had a higher GDP per capita in 2011 than the Nordic threshold. Table 1 disaggregates the 81 countries by region: 31 countries are in Europe (38\%), 18 are located in the Americas ${ }^{20}(22 \%), 14$ in Asia (17\%), nine located in the Middle East (11\%), 7 in Africa (9\%) and finally 2 in Oceania (3\%). Besides, there are four countries less than 200 USD shy from the Nordic average: Colombia, Costa Rica, Ukraine and Saint Lucia. If the median GDP per capita is used as the Nordic threshold, then an additional country (Colombia) joins the previous 81 cases referenced above.

\footnotetext{
${ }^{18}$ The data used to calculate the Nordic average is comprised of Sweden (1950), Finland (1956), Norway (1957), and Denmark (1960). Sweden is the only country where data does not correspond to the year of implementation of the basic pension.

${ }^{19}$ Because of data limitations, neither median household income nor median individual income could be used to operationalise the variable. The limitation refers to the data of the Nordic countries in the $1940 \mathrm{~s}-1950 \mathrm{~s}$.

${ }^{20}$ According to Stephens (2002) since 1980's, and 1990's Latin American countries reached the per capita income level of European countries by the time they first implemented flat-rate pensions.
} 
Figure 1: Countries with a GDP per capita higher than the Nordic average by the time they implemented the first universal basic security pensions (PPP, in 2005 USD).

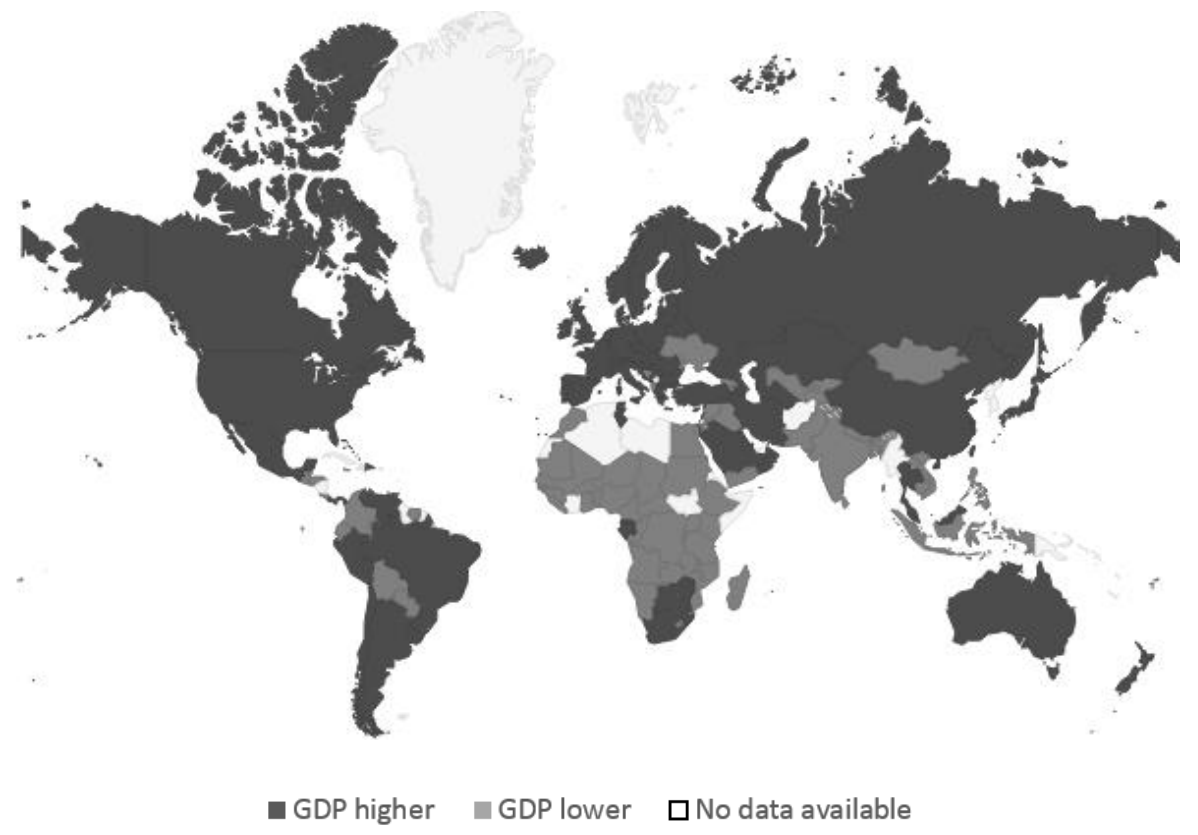

Notes: The map shows 81 countries with a GDP per capita (PPP) higher than Sweden, Norway, Denmark and Finland by the time they implemented the first universal basic security pensions (dark grey). Eighty-one additional countries with a GDP per capita below the Nordic countries average are in light grey. Countries with no data available are in white. Data is for 2011.

Author's calculations; Source: (Feenstra et al., 2015)

Countries listed in Table 1 are categorised as high and middle-income countries according to the World Bank. We could argue social provision is most needed in lowincome countries, mainly because the one billion most impoverished individuals, on a multidimensional scale (i.e., the bottom billion), live in the 28 poorest countries, according to the country-level MPI. However, Alkire, Roche, Seth, and Sumner (2014) argue that by counting the poor living in the poorest sub-national regions, the picture morphs into one which the poorest are located in 307 regions across 45 countries. If we zoom in even further, and rank individuals according to their poverty profile, the bottom billion (those with the highest intensity of poverty) are then distributed across 104 countries. This problem is commonly cited as a facet of the Modified Areal Unit Problem (MAUP), wherein statistical bias occurs on account of arbitrary geographic delimitations.

As Alkire and Robles Aguilar (2015) suggests, "zooming in on poverty at a sub-national or even the individual level is vital to shine a light on the different levels and characteristics of poverty within countries and help to design high-impact policy responses". Therefore, in order to be able to include a vast majority of individuals in poverty (including the older population) the implementation of universal pensions throughout the world could counter exclusions resulting from these and other issues in high, middle and low-income countries. If we consider assumption 1 to be true, then the 81 countries presented in Figure 1 have the economic viability to develop and implement 
a universal non-contributory pension program, taking as an example the threshold used by the Nordic, universal welfare states.

Table 1: List of countries with a gross domestic product per capita (PPP) higher than the Nordic average by the time they implemented the first universal basic security pensions.

\begin{tabular}{|c|c|c|c|c|c|c|}
\hline \multicolumn{2}{|c|}{ Europe } & Americas & Asia & Middle East & Africa & Oceania \\
\hline Norway & Greece & United States & $\begin{array}{c}\text { Brunei } \\
\text { Darussalam }\end{array}$ & Qatar & $\begin{array}{c}\text { Equatorial } \\
\text { Guinea }\end{array}$ & Australia \\
\hline Luxembourg & Czech Republic & Canada & Singapore & Kuwait & Gabon & $\begin{array}{c}\text { New } \\
\text { Zealand }\end{array}$ \\
\hline Switzerland & Malta & Bermuda & Hong Kong & Oman & Botswana & \\
\hline Ireland & Portugal & $\begin{array}{c}\text { Trinidad and } \\
\text { Tobago }\end{array}$ & Taiwan & $\begin{array}{l}\text { Saudi } \\
\text { Arabia }\end{array}$ & Zimbabwe & \\
\hline Netherlands & Slovakia & Bahamas & Japan & Bahrain & Mauritius & \\
\hline Denmark & Estonia & Barbados & Republic of Korea & Israel & South Africa & \\
\hline Austria & Poland & Chile & $\begin{array}{c}\text { Russian } \\
\text { Federation }\end{array}$ & Lebanon & Tunisia & \\
\hline Germany & Hungary & Argentina & Maldives & Turkey & & \\
\hline Sweden & Croatia & Panama & Malaysia & Iran & & \\
\hline Finland & Lithuania & Mexico & Kazakhstan & & & \\
\hline Belgium & Belarus & Uruguay & Turkmenistan & & & \\
\hline Iceland & Latvia & Venezuela & Azerbaijan & & & \\
\hline $\begin{array}{l}\text { United } \\
\text { Kingdom }\end{array}$ & Romania & $\begin{array}{l}\text { Antigua and } \\
\text { Barbuda }\end{array}$ & Thailand & & & \\
\hline France & Montenegro & Dominica & China & & & \\
\hline Italy & Bulgaria & $\begin{array}{c}\text { Saint Kitts and } \\
\text { Nevis }\end{array}$ & & & & \\
\hline Spain & Serbia & Brazil & & & & \\
\hline Cyprus & FYR & Dominican & & & & \\
\hline & Macedonia & Republic & & & & \\
\hline Slovenia & & Peru & & & & \\
\hline
\end{tabular}

Notes: This list consists of 81 countries and the 4 Nordic countries considered (Norway, Sweden, Finland and Denmark).

Latest data available at the Penn World Table 8.1 was used. The variable used is output-side real GDP per capita attained PPPs (in mil. 2005 US\$) for the year 2011.

Author's calculations; Source: (Feenstra et al., 2015)

If a country must indeed overcome a specific economic performance barrier before it can implement a universal basic security pension, then approximately $51 \%$ of the world population $^{21}$ lives in countries with enough economic resources. The question is then why less than $10 \%$ of countries in the world have introduced a basic universal noncontributory pension? Should academics and policymakers be talking about political will and ideology instead of using the alleged lack of economic capacity of countries as a constraint to implement universal non-contributory pensions? Political will refers to the determination of politicians to make the necessary reforms to implement universal noncontributory social pensions, at least in countries that meet the assumed requirement of economic development as a prerequisite for economic viability. The ideology and driving forces from Mkandawire are discussed above.

Nonetheless, at least 17 countries with a relatively low level of economic performance ranked 100 or below in terms of GDP per capita (PPP I\$) - have implemented universal

${ }^{21}$ The PWT data is available for 166 countries, with a total population of 6.718 billion people. The 81 countries with a GDP per capita higher than the Nordic average plus the 4 Nordic countries have a total population of 3.446 billion. 
non-contributory pensions without means targeting for citizens and residents. Kiribati, Samoa, Timor-Leste, Bolivia, Guyana and Namibia, have all implemented universal social pensions for citizens and residents. Uganda, Nepal, Papua New Guinea, Tajikistan, Moldova, Vietnam, Uzbekistan, Armenia, Swaziland, and most recently Tanzania have implemented non-contributory pensions with additional targeting besides age (e.g. regional, pensions-tested, or in combination) for citizens and residents.

Bolivia, Georgia, Namibia and Suriname have already developed extensive and inclusive non-contributory pensions for citizens and residents without having overcome the historic Nordic GDP per capita 'barrier'. According to the Pension Watch country fact sheet, Bolivia's 'Renta Dignidad' or 'Renta Universal de Vejez' ('Dignity pension' and 'Universal Old-Age Pension' respectively) were introduced in 1997, Georgia's Old-Age Pension started in 2006, Namibia's Old-Age Pension was introduced in $1992^{22}$, and Suriname's 'Algemene Oudedags Voorzieningsfonds' ('State Old-Age Pension') started back in 1973. Table 2 provides a detailed description of benefits, age of eligibility, targeting and population covered across these four universal non-contributory pension schemes for citizens and residents. These countries illustrate the need to appropriately consider the assumed binding relationship between economic performance and universal social protection in older age.

Table 2: Universal non-contributory older-age pensions for citizens and residents in Bolivia, Georgia, Namibia and Suriname

\begin{tabular}{|c|c|c|c|c|c|c|c|c|c|}
\hline \multirow[b]{2}{*}{ Country } & \multirow[b]{2}{*}{$\begin{array}{l}\text { Name of } \\
\text { scheme }\end{array}$} & \multirow[b]{2}{*}{ Year } & \multirow[b]{2}{*}{$\begin{array}{l}\text { Age of } \\
\text { eligibility }\end{array}$} & \multicolumn{3}{|l|}{ Benefit level } & \multicolumn{3}{|c|}{ Beneficiaries } \\
\hline & & & & $\begin{array}{l}\text { Monthly } \\
\text { pension in } \\
\text { local } \\
\text { currency }\end{array}$ & $\begin{array}{l}\text { Monthly } \\
\text { pension } \\
\text { in \$US } \\
\text { PPP }\end{array}$ & $\begin{array}{l}\% \\
\$ 1.25 \\
\text { poverty } \\
\text { line }\end{array}$ & $\begin{array}{l}\text { Number } \\
\text { of } \\
\text { recipients }\end{array}$ & $\begin{array}{l}\% \\
\text { Population } \\
60+ \\
\text { covered }\end{array}$ & $\begin{array}{l}\% \\
\text { Population } \\
\text { over } \\
\text { eligibility } \\
\text { covered }\end{array}$ \\
\hline & Renta & & & 250 & & & & & \\
\hline Bolivia & Dignidad & 1997 & 60 & bolivianos & 80 & $211 \%$ & 902749 & $91 \%$ & $91 \%$ \\
\hline Georgia & $\begin{array}{l}\text { Old age } \\
\text { pension } \\
\text { Old Age }\end{array}$ & 2006 & $\begin{array}{l}65 \text { men; } \\
60 \text { women }\end{array}$ & 100 tlari & 101 & $264 \%$ & 662000 & $79 \%$ & $106 \%$ \\
\hline Namibia & $\begin{array}{l}\text { Pension } \\
\text { Algemene }\end{array}$ & 1992 & 60 & $1000 \mathrm{~N} \$$ & 159 & $417 \%$ & 152272 & $114 \%$ & $114 \%$ \\
\hline Suriname & $\begin{array}{l}\text { Oudedags } \\
\text { Voorzienings- } \\
\text { fonds }\end{array}$ & 1973 & 60 & $\begin{array}{l}500 \\
\text { Surinamese } \\
\text { Dollar }\end{array}$ & 253 & $665 \%$ & 42818 & $92 \%$ & $92 \%$ \\
\hline
\end{tabular}

Assumption 2: Means-tested targeting is more efficient than a universal social provision for allocating resources in a time of budget constraints and globalisation

The premise underlying this assumption is that because of limited resources, the best approach to identify the poor and provide social assistance is through means-tested targeting. Under this assumption, means targeting is considered to be more efficient than universalism (i.e. means-testing performs better to select the 'deserving poor' than

${ }^{22}$ It was introduced for whites in 1949 and on a universal basis in 1992 (HelpAge International, 2015b). 
universalism, and it does so with the least amount of resources). Means testing is considered to be more cost-efficient than universalism, allowing redistribution of income to where it is most needed.

The dominating ideology and preference of International Finance Institutions have influenced the structure of social protection programmes in the Global South via social policy diffusion by promoting targeting and conditionalities in social policy. (See Heimo, 2019; Brooks, 2015; Osorio Gonnet, 2018). Kidd (2018) argues, "social protection comprises a significant share of World Bank loans, reaching almost 10 per cent of lending to low-income countries in 2017, while around 10 per cent of IMF loans include conditionality linked to social protection”. The Bank's ideology and preferences regarding social protection have had an impact shaping and consolidating the assumption that targeting and conditionalities are more efficient than universalism in selecting the 'deserving poor' with the least amount of resources.

Targeting implies a range of techniques to identify those considered as the "most needy" and "deserving poor". Is means-tested targeting truly efficient in identifying those considered as "poor"? According to Danson, McAlpine, Spicker, and Sullivan (2012, p. 1), "the selective element of pension entitlement is more than 50 times more inefficient than the universal element measured in terms of fraud and error alone and without even taking into account the cost of administration" [emphasis added]. The World Bank (2007) confirms that complex eligibility requirements make social protection programs more prone to error, fraud and corruption. The costs of administration of social provision targeted by means are higher than in universal strategies owing to the intrinsic need to verify any and all eligibility criteria (Bowles, Gintis, \& Wright, 1998, p. 240). This extra level of administration creates a somewhat arduous negative side effect of moving away from universalism - inclusion and exclusion errors (van Oorschot, 2002, p. 175). ${ }^{23}$ By targeting social provision, governments must identify who is poor and who is not, and in this process, these errors are inevitable (Sen, 1995).

What about the socio-economic effects of means-tested targeting? Selectivity increases social and economic inequality (Danson et al., 2012, pp. 1-2). The process of proving the status of deprivation is typically humiliating for any individual, often taken as a mark of shame (Gubrium, Pellissery, \& Lødemel, 2014) and stigmatisation (Gilens, 1999; Titmuss, 1976). Means-tested benefits may create disincentives for individuals to save and participate in societal consumption smoothing by knowing beforehand they will be able to apply to means-tested pensions in the future (Feldstein \& Liebman, 2002). Besides, means testing conflicts with the broader aims of social policy: ending poverty and dependency, social integration and social justice (van Oorschot, 2002, p. 175).

According to Kidd (2015), universal social protection programmes generate higher budgets and allocate higher transfers - to those considered as poor - than means-tested

\footnotetext{
${ }^{23}$ Inclusion errors (type-I errors) refer to the act of including individuals as beneficiaries of a social program -due to inaccurate targeting- who do not meet the eligibility criteria. Exclusion errors (type-II errors) refer to the act of excluding individuals as beneficiaries of a social program -due to inaccurate targeting- although having the eligibility criteria to be a beneficiary.
} 
schemes because they have more political support. Moreover, universalism creates "flatter income distributions" than means-testing (Danson et al., 2012, p. 2). Anttonen, Häikiö, and Stefánsson (2012, p. 193) argues that "unlike residual benefits, universal flatrate cash benefits do not create 'income traps' that impede participation in the labour force"; furthermore, the administrative efficiency of universal programmes is, they argue, "marvellous compared to selective programmes".

A recent review of targeting social transfers in developing countries published by Devereux et al. (2015) found 85 sources of evidence, covering around 30 social protection programmes in 41 countries. In particular ${ }^{24}$ :

- No single target mechanism works best in all contexts.

- Exclusion and inclusion errors are inevitable, "perfect targeting is possible in theory but effectively impossible in reality".

- Administrative costs are higher in means testing than in regional and universal approaches.

- There are numerous costs associated with targeting that should be considered in addition to administrative costs: private costs to applicants (e.g. transport, documentation), social costs (e.g. the creation of divisions in the communities between beneficiaries and non-beneficiaries), psycho-social costs (e.g. stigmatisation), political costs (due to universal programmes generate broader political support), incentive costs (caused by the eligibility criteria, may promote specific behavioural changes such as fertility, job-search).

- Means-testing is not only expensive but inaccurate.

With the goal of efficiency in mind, countries around the world have, over the last decades, curiously favoured means-tested social policies to identify and alleviate the income poor. Because of the scarcity of reliable data, combined with the large informal economies in "less-developed" countries, it is difficult to assess individual/household incomes. Instead of putting questionable social protection systems into place, many have instead moved forward with highly advanced statistical methods with seemingly little attention paid to the ramifications of the limitation of their option - i.e. proxy-means testing. The proxy-means tested (PMT) methodology was designed to tackle the dearth of information required for accurate means testing by using household proxies to estimate household welfare.

According to Kidd and Wylde (2011, p. 1), the logic behind this methodology is the application of (linear) regressions between welfare and household characteristics (e.g. demographic, human capital, housing infrastructure, durable goods, productive assets) to identify a list of proxies that best explain household expenditures. By assigning weights to these proxies (relative to the correlation degree), a score is calculated for each household which is then used to assign a threshold as the eligibility criteria to receive targeted benefits.

${ }^{24}$ Devereux et al. (2015: 45-48). 
Studies often "portray the PMT as a scientific and technocratic solution to poverty targeting" Kidd and Wylde (2011, p. 2). While the PMT may be considered scientific and even technocratic, it remains questionable whether one ought rightly to consider this mode a solution to poverty targeting. After analysing the accuracy of the PMT methodology in Bangladesh, Indonesia, Rwanda and Sri Lanka, Kidd and Wilde reveal significant inclusion and exclusion errors. Considering 10 per cent and 20 per cent of the population as beneficiary of the PMT program (coverage level), they find that "eligible households have no better than one-in-two chance of being selected, and in some cases even view proxy means testing as a lottery" Kidd and Wylde (2011, p. 31).

Ahmed \& Bouis (2002) presents with satisfaction the PMT model used to predict and select the "needy" and "non-needy" households in Egypt for food subsidies. The research highlights one of the alleged benefits of this complex statistical technique, which is expected to save economic resources for the government by lowering the budgetary costs of rationed food subsidies. Klasen \& Lange (2015) consider PMT as a useful solution to the absence of reliable income data in large part of the Global South. However, based on a ROC-analysis the researchers confirmed the poor performance of the PMT to identify the income poor in Bolivia. Using a sample of nine African countries, Brown, Ravallion \& van de Walle (2018) recently confirmed that the popular PMT excludes a large amount of income-poor individuals, thus negatively impacting the poverty reduction effect of PMT. In the researchers' own words, PMT and"the prevailing methods are particularly deficient in reaching the poorest" (2018, p. 109).

Emerging research in developing contexts, where the PMT is put forward, supports the concern surrounding this mode of targeting. In the Philippines, recent work illustrates the innate concerns of exaggerating the benefits of PMT, primarily as concerns older-age poverty (Knox-Vydmanov, Horn, \& Sevilla, 2016). Firstly, it must be remembered that pensions target individuals, not households. The PMT eligibility criterion, however, is based on household poverty, failing to capture intra-household poverty differences. Using Southern Africa survey data, Bhorat (1999, p. 157) shows that poverty measures at the individual level and the household level "transmit differential rankings of indigence". Vijaya, Lahoti, and Swaminathan (2014, p. 70), using the Karnataka Household Asset Survey (India), show that "individual-level measures can identify substantial gender differences in poverty that are masked when using household measures. Thus, genderdisaggregated data and analysis can provide a useful complement to household level poverty measures". If household poverty does not present the actual deprivations of the individuals in the household, then, by definition, PMT is incapable of accurately identifying the levels of deprivations suffered by individuals in poverty.

Second, poor older persons may not be asset-poor. PMT assumes that the assets a household has strongly reflect the income of a household. However, as the Philippines evidence points out, "the correlation between assets and income is often quite weak" (Knox-Vydmanov et al., 2016, p. 46). This again involves the unavoidable risk of inclusion and exclusion errors. Finally, many poor older persons live in smaller households. The PMT methodology used in the Philippines, for instance, benefits 
households with many members in the selection process, undermining many older individuals living alone or in small households who are income poor. ${ }^{25}$

If there were no targeting errors and zero targeting costs, then there would be no reason to doubt that targeting is the most efficient approach in times of budget constraints and globalisation. The social pension in Nepal exhibits an exclusion error (measured by age eligibility) of 23 per cent, while in Brunei the figure is 13 per cent (Willmore, 2007). In Azerbaijan, the exclusion error (measured by poverty status) is 95.2 per cent, and the inclusion error is around 86.1 per cent (Habibov \& Fan, 2006). As these cases demonstrate, targeting is not as efficient as international financial institutions have claimed. Therefore the population identified as the "most needy" is not benefiting from the alleged powers of targeting on identifying the income poor.

Assumption 3: With an under-developed taxation system there is no alternative than to target the income poor to alleviate monetary deprivations

The main logic behind this assumption is the economic constraint faced by countries with a non-institutionalized or inadequate tax system. Consequently, most of the arguments used in the previous section apply here too. Taxation is one of the primary funding sources for governments; therefore, underdeveloped capacity marks a severe limitation on the ability of governments to mobilise and direct resources for public purposes. A limited tax burden and a regressive tax system limit the financing capacity of low and middle-income countries to develop a comprehensive welfare system. According to Barrientos (2007, p. 11), "financing is a key constraint on the development of social protection".

Tax revenues are considerably lower in the developing world than in, say, the European region. According to the 2015 Index of Economic Freedom, the tax burden as a percentage of Gross Domestic Product (GDP) is around 33.2 per cent in Europe, 20.3 per cent in Latin America and the Caribbean, 16.8 per cent in Sub-Saharan Africa and just 10.3 per cent in the Middle East and North Africa. ${ }^{26}$ This is indeed a significant limitation, which must be addressed and urgently taken into account. The need to implement, restructure and develop a progressive taxation system is a generally accepted issue. Does this entail, however, that low and middle-income countries are destined to implement means-tested programs with "poor benefits" (Sen, 1995) because of this limitation? Are older persons across the world doomed to suffer multiple deprivations and social risks because their national governments do not yet have what could be considered a "developed tax system"? While not addressed in this brief, these issues must be considered with due diligence.

\footnotetext{
${ }^{25}$ This is mainly due to a disconnect with the original intention of that country's PMT (targeting poor households with children for the country's child-focused poverty program - i.e., the Pantawid Pamilyang Pilipino Program) and the purpose it has come to be used for, addressing older age poverty

${ }^{26}$ Author's calculation using data from The Heritage Foundation (2015).
} 
According to the latest HelpAge International (2015a) database, there are 102 countries with non-contributory pension programmes. We could argue these countries have already acknowledged the power of non-contributory pensions to promote wellbeing and quality of life among the older population. However, only 17 countries provide universal noncontributory pensions, with the rest implementing additional forms of targeting (e.g. regional, means-tested, residence, or a combination of them) to identify the 'truly deservers' among the older population. How much do governments in these countries need to invest in order to be able to abandon additional forms of targeting and provide universal benefits to every older person? Is it that costly as it is argued? Why are those countries hesitant regarding universalism; is it only about the costs?

Using age-disaggregated data from the United Nations Population Division (UNPD, 2015) we can estimate the investment needed to implement a universal non-contributory pension in countries which have already implemented means-tested/regional-tested noncontributory pensions. To calculate the investment needed for universal pensions, we use a modified model of Willmore's (2007) formula previously proposed by KnoxVydmanov (2011, p. 3), where $5 \%$ of the total cost of transfers is added as an administrative cost Knox-Vydmanov (2011, p. 3). This formula is given as:

$$
S i=r p+A c
$$

Where $S i$ is the social investment needed - in percentage points of GDP - to implement a basic universal non-contributory pension, $r$ is the ratio of the flat pension to per capita GDP (pension level), $p$ is the proportion of the population eligible for pensions (age eligibility), and $A c$ is the administrative cost of the transfer. The data used is from 2015 and allows the inclusion of 79 countries which have already implemented meanstested/regional-tested non-contributory pensions.

The age eligibility for actual pensions also varies considerably between countries. In order to examine different scenarios, five eligibility ages are considered: 50, 60, 65, 70, and 75 . Besides, two pension levels scenarios are considered: a pension equivalent to $10 \%$ (scenario 1) and 20\% (scenario 2) of GDP per capita. Countries included in this study have diverse economic, social and political realities; therefore, these pension levels should be considered as 'lab tests' - arbitrarily assigned - and do not necessarily represent an adequate basic income for all countries. ${ }^{27}$

Figure 2 shows the investment needed to implement a universal non-contributory pension with a benefit level of 10\% GDP per capita, while Figure 3 shows the benefit level of $20 \%$ GDP per capita. With less than $1.2 \%$ of the respective national GDPs, all 79 countries would be able to shift from targeted non-contributory pensions to universal non-contributory pensions with a benefit level of $10 \%$ of GDP per capita and with an age of eligibility of 75 . This number is increased to $2.4 \%$ of GDP if the benefit level is

${ }^{27}$ Knox-Vydmanov (2011, p. 5) justified the use of $20 \%$ of GDP per capita as a "reasonable" pension level for low and middle-income countries. By making a comparison of the benefit levels from universal pensions in low and middle-income countries, the author showed that a large number of pensions exhibited a benefit level between $10 \%$ and $20 \%$. 
increased to $20 \%$ of GDP per capita. We can continue doing this analysis of the two scenarios of benefit levels while reducing the age of eligibility to 70, 65, 60 and 50 (see Figure 2 and 3 ).

According to the latest data from Pension Watch, 16 countries ${ }^{28}$ have tested (means and/or regional), non-contributory pensions more expensive than a hypothetical universal pension with a benefit level of 10 per cent of GDP per capita and with an age of eligibility of 75. For example, Trinidad and Tobago and Venezuela would be able to finance a universal pension with a benefit level of 10 per cent of GDP per capita and with an age of eligibility of 65. South Africa and Australia would be able to finance a pension with a similar level as Trinidad and Tobago and Venezuela but for every individual above 60, and Lesotho for every individual above 50.

Using 75 as the eligibility age may not be ideal, especially for low and middle-income countries where life expectancy is shorter than for high-income countries. For example, according to the latest 2015 UNPD data, while individuals over 75 years of age represent $7.5 \%$ of the population in high-income countries, this number is a third $(2.4 \%)$ in middleincome countries and more than one-seventh $(1.0 \%)$ in low-income countries. To solve this issue, Knox-Vydmanov $(2011$, p. 2) proposed to begin implementing social pensions with a higher eligibility age in order to lower its initial cost, "with the intention to gradually reduce the eligibility age as political support and financial resources grow".

According to Freeland (2013, p. 3), the unaffordability argument of universal social protection is (unnecessarily and overly) exaggerated, "affordability is much more closely associated with political will than with fiscal resources". Governments need resources to implement a social protection program (e.g. pensions) on a universal basis, and a progressive, developed tax system would decidedly facilitate its economic viability. However, governments across the world have budgets and resources allocated to different areas. What would happen if governments started to shift budget resources from nonproductive areas to social protection? How long could a universal social pension scheme in a low or middle-income country be funded with non-productive resources spent on high-income countries?

\footnotetext{
${ }^{28}$ Australia, Brazil, Cape Verde, Costa Rica, Denmark, Finland, Lesotho, Maldives, Mozambique, Nepal, Norway, Paraguay, South Africa, Swaziland, Trinidad and Tobago, and Venezuela
} 
Figure 2: Social investment required to implement a basic universal pension equivalent to $10 \%$ of the GDP per capita in 79 countries with means-tested and regional tested non-contributory pensions

$\square+75 \square+70 \quad+65 \quad \square+60 \quad+50$

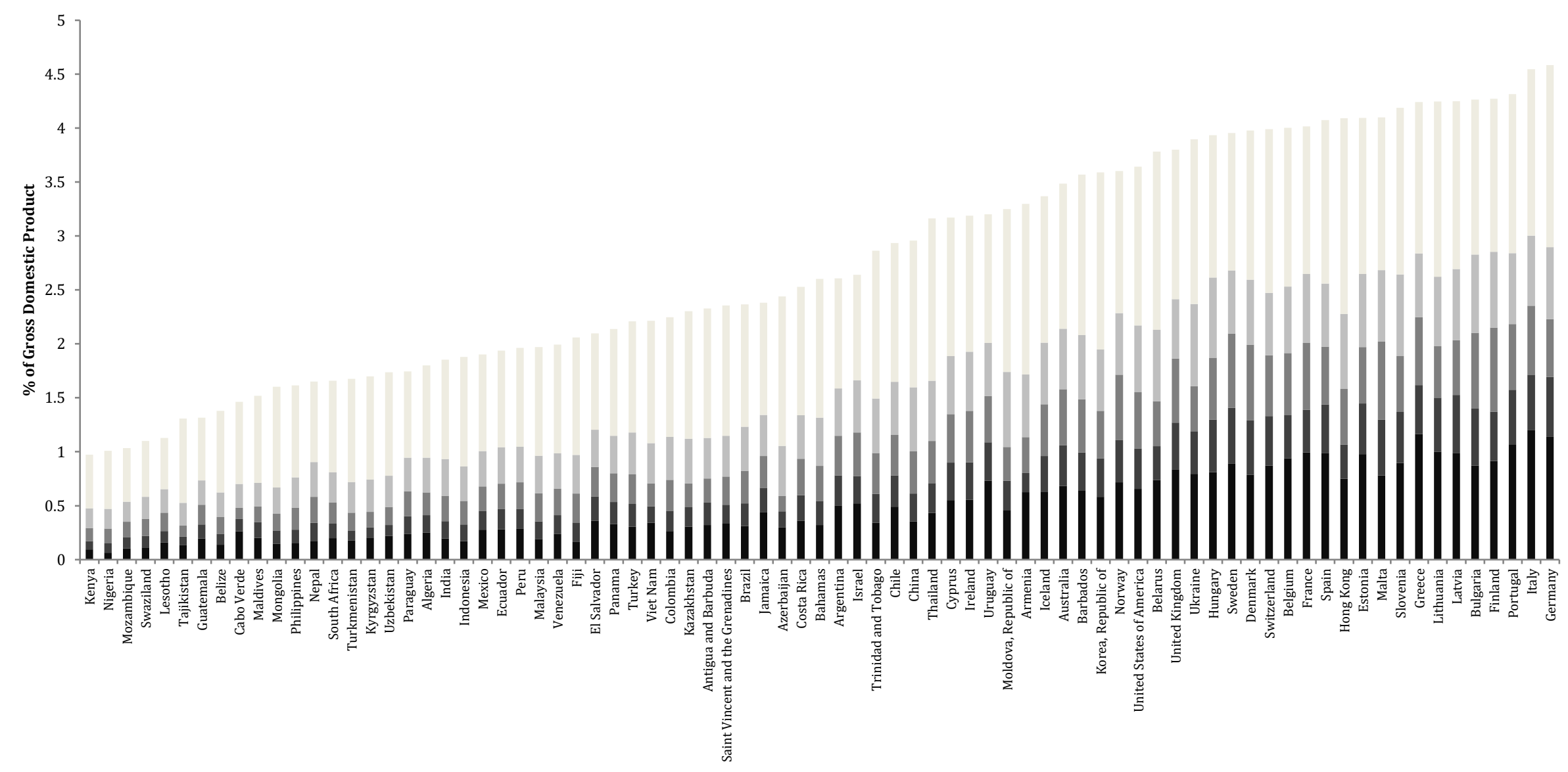

Author's calculations; Source: (UNPD, 2015) 
Figure 3: Social investment required to implement a basic universal pension equivalent to $20 \%$ of the GDP per capita in 79 countries with means-tested and regional tested non-contributory pensions

$\square+75 \square+70 \quad+65 \quad \square+60 \quad+50$

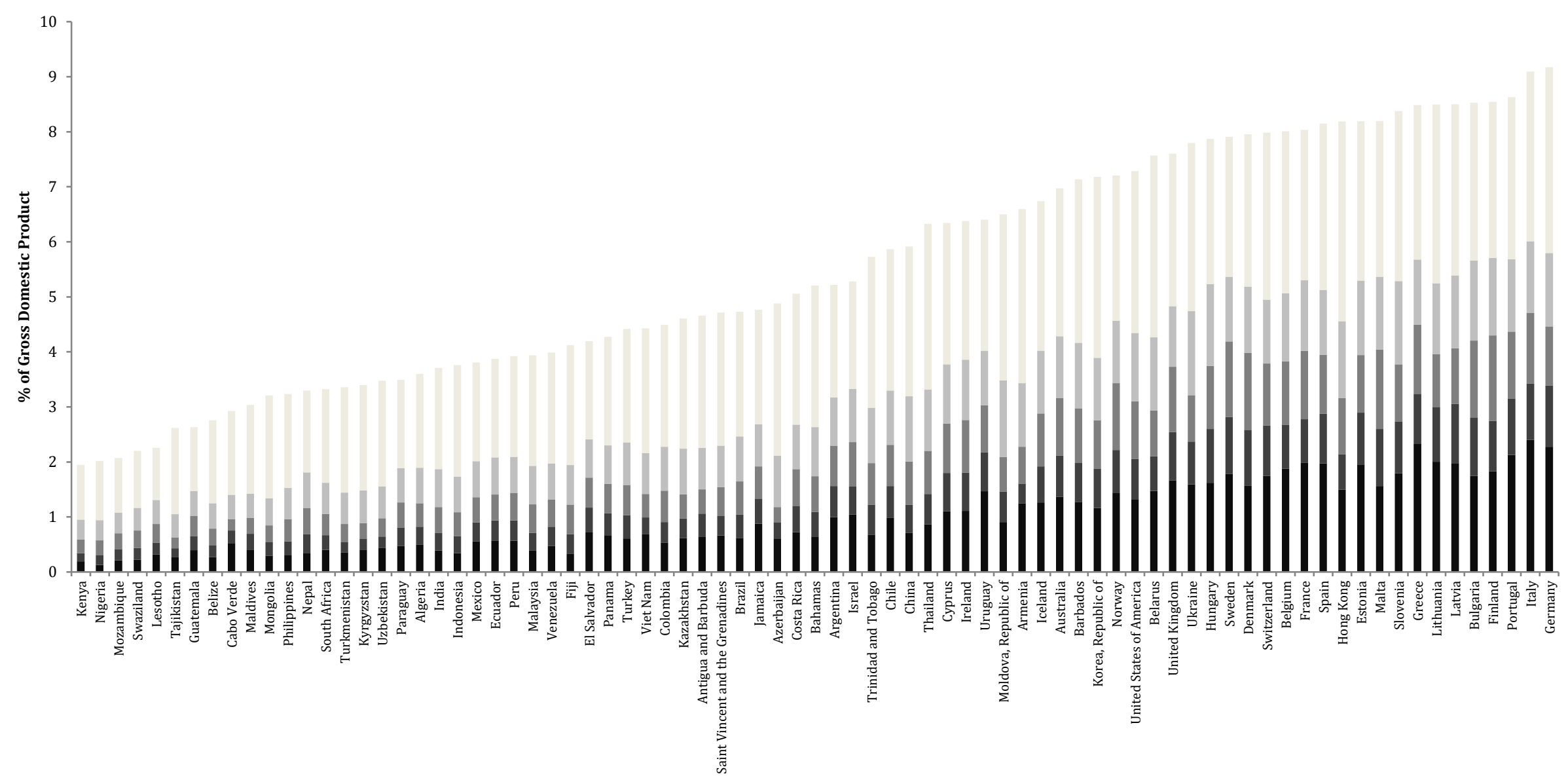

Author's calculations; Source: (UNPD, 2015) 
Here it is useful to consider some spending priorities - particularly military expenditures. For example, with the resources Algeria used in 2014 on military expenditures, it would be able to finance a universal non-contributory pension with a benefit level of $20 \%$ GDP per capita and an eligibility age of 50 . That means that around $17.1 \%$ of the population would benefit directly from this pension system, with around 1.8\% of its GDP remaining for military expenditures (SIPRI, 2015). ${ }^{29}$ Israel, for example, could be using its military expenditure to subsidise a basic universal pension with the same benefit level and age of eligibility as Algeria in the previous example. The same is true for Armenia (benefit level of $20 \%$ GDP per capita and an age of eligibility of 60), Azerbaijan (benefit level of $20 \%$ GDP per capita and an age of eligibility of 60), the United States (benefit level of 20\% GDP per capita and an age of eligibility of 65), India (benefit level of $20 \%$ GDP per capita and an age of eligibility of 60), and so forth.

What about electoral spending? According to the Center for Responsive Politics (2015), the total cost of the United States of America's 2012 election was 6.3 billion USD. ${ }^{30}$ This amount is equivalent to about $0.04 \%$ of 2012 US GDP, and would not be enough to finance even a universal non-contributory pension with a benefit level of $10 \%$ and age of eligibility 75 in this country. However, with this amount of resources national universal non-contributory pensions could be financed in other places. For example, Kenya would be able to finance universal non-contributory pensions for six years (benefit level of $20 \%$ GDP per capita and an age of eligibility of 50), Mozambique a similar pension for 21 years, Swaziland would be able to finance a similar pension for 76 years, and it would even be enough to finance a universal non-contributory pension for India (benefit level of $10 \%$ GDP per capita and an age of eligibility of 70). ${ }^{31}$

Examples abound, but it should be clear that even with 'under-developed' tax systems and all the other limitations of low and middle-income countries, there are enough resources in this world to avoid most, if not all, of the basic income deprivations which older persons suffer.

\section{CONCLUSION}

Universal social pensions are politically and economically viable as well as efficient strategies to alleviate poverty. This paper has illustrated that universal non-contributory pensions could be successfully implemented in countries with low economic performance, despite arguments to the contrary. However, for those who support the alleged requisite of reaching a certain degree of economic development before implementing universal social pensions, 75 countries have surpassed this economic threshold and still have not implemented universal social pension.

\footnotetext{
${ }^{29}$ A military expenditure of $1.8 \%$ GDP remains higher than those of Germany, Japan, Brazil, Italy among many others.

${ }^{30}$ This amount was constructed adding the approximately 3.7 billion spent in the congressional races and 2.6 billion spent in the presidential race.

${ }^{31}$ GDP data used is for 2012 and comes from the World Bank.
} 
Budget constraints are indeed a limitation for implementing social welfare policies (universal or targeted). Nonetheless, the existing scholarship is not unanimously behind the cause of means testing and instead indicates that targeting by means in social provision is not more efficient than a universal provision of benefits. Means-tested comes with higher administrative costs, clientelism, inclusion and exclusion errors, and the stigmatisation of beneficiaries. The evidence emerging from the Philippines is illustrative of these concerns. First, PMT does not capture intra-household poverty differences, even though pensions are targeted to individuals. Second, asset deprivation does not accurately equate to income deprivation, though this is assumed in the process. Third, PMT disadvantages older persons living alone or in small households, excluding individuals with income deprivation from social pensions.

A limited tax burden and a regressive tax system bound the financing capacity of low and middle-income countries from the development of comprehensive welfare systems. While this limitation should be addressed with urgency, it should not be an overriding excuse to combine multiple types of targeting over universal targeting (universal benefits for the older population). Using five scenarios of age eligibility and two scenarios of benefit level in 79 countries, this paper has illustrated that universal social pensions are affordable. This economic viability needs to be accompanied with the political will to implement social pensions based on concepts of social justice and development. The international community needs to incentivise the capacity building of low and middleincome countries. A social welfare system needs to be institutionalised in order to be able to maintain the social protection schemes for the future.

\section{THE ROAD AHEAD}

Universal targeting, overall, comes out on top as the social policy approach to follow, as a first step in the development of social protection systems. Scholars in Latin America have been arguing in favour of 'basic universalism' as an option to reform social policy in the region. This social policy proposal has four pillars: universal targeting, high quality benefits for all individuals, a central role of the State in the implementation of such policies, and (finally) the needs to create a tailored basic universalism for each country meeting the needs of its population and taking into account its fiscal/political/economic possibilities (Cecchini, Filgueira, Martínez, \& Rossel, 2015; Molina, 2006).

Essentially, what basic universalism proposes for low and middle-income countries is the need to reinvent universalism, as we know it from high-income Nordic countries. The idea is to start by implementing basic security policies that, with time and support, will be able to evolve into institutionalised and universal welfare systems. Such pension systems should consist of: basic universal pensions (as a social protection floor for the older-age population), targeting within universalism (making universalism more effective), and earnings-related contributory pensions as complementary earnings to promote employment in the formal sector and increase contributions to the social security programs. The world has the resources to implement this on a global scale; the question is if there is also the political will to undertake the necessary reforms. 


\section{ACKNOWLEDGMENTS}

Previous versions of this article were written while the author was a Postdoctoral Research Fellow at the University of Agder, and a Research Fellow in Social Protection at HelpAge International. The author gratefully acknowledges valuable feedback and edits from Daniel Horn. Charles Knox - Vydmanov, Flavia Galvani, Aderonke Gbadamosi, Alice Livingstone, and blind reviewers provided much - appreciated comments on earlier drafts of this article. Special thanks to my research assistant, Anni Chen. Supported by the Spanish Ministry of Economy, Industry and Competitiveness (FJCI - 2016 - 29871 \& GOWPER - CSO2017 - 85598). Shortcomings, of course, remain my responsibility.

\section{REFERENCES}

Ahmed, A. U. and H. E. Bouis (2002). "Weighing What's practical: Proxy Means Tests for Targeting Food Subisidies in Egypt." FCND Discussion Paper, 132, Retrieved from: https://core.ac.uk/download/pdf/6289481.pdf.

Alkire, S., \& Robles Aguilar, G. (2015). High Visibility. How disaggregated metrics help to reduce multidimensional poverty. OPHI Brief 28, , Oxford University.

Alkire, S., Roche, J. M., Seth, S., \& Sumner, A. (2014). Identifying the Poorest People and Groups: Strategies Using the Global Multidimensional Poverty Index. OPHI Working Paper 78, , Oxford University.

Anttonen, A., Häikiö, 1., \& Stefánsson, H. (2012). The future of the welfare state: rethinking universalism. In A. Anttonen (Ed.), Welfare State, Universalism and Diversity. Cheltenham: Edward Elgar.

Barnett, W. S., Brown, K., \& Shore, R. (2004). The universal vs. targeted debate: should the United States have preschool for all? Preschool Policy Matters, 6, NIEER.

Barr, N. (2012). Economics of the Welfare State. Oxford: Oxford University Press.

Barr, N., \& Diamond, P. (2006). The Economics of Pensions. Oxford Review of Economic Policy, 22(1), 15-39.

Barrientos, A. (2007). Introducing basic social protection in low-income countries: Lessons from existing programmes. Brooks World Poverty Institute Working Paper, 6, University of Manchester.

Bastagli, F. (2013). Feasibility of social protection schemes in developing countries. Belgium: European Union.

Bauman, Z. (2014). ¿La riqueza de unos pocos nos beneficia a todos? Barcelona: Ediciones Paidós Ibérica, S.A.

Bhorat, H. (1999). Distinguishing between individual- and household-level poverty. Development Southern Africa, 16(1), 157-162.

Bowles, S., Gintis, H., \& Wright, E. O. (1998). Recasting Egalitarianism: New Rules for Communities, States and Markets. New York: England.

Brooks, S. M. (2015). "Social Protection for the Poorest:The Adoption of Antipoverty Cash Transfer Programs in the Global South." Politics \& Society 43(4): 551-582.

Brown, C., Ravallion, M. \& van de Walle, D. (2018). "A poor means test? Econometric targeting in Africa." Journal of Development Economics 134: 109-124. 
Carroll, E., \& Palme, J. (2006). Inclusion of the European Nordic Model in the Debate Concerning Social Protection Reform: The Long-term Development of Nordic Welfare Systems (1890-2005) and Their Transferability to Latin America in the Twenty-first Century. Santiago de Chile: ECLAC, Special Studies Unit, Sida.

Cecchini, S., Filgueira, F., Martínez, R., \& Rossel, C. (2015). Instrumentos de protección social. Caminos Latinoamericanos hacia la universalización. Santiago de Chile: Comisión Económica para América Latina y el Caribe.

Center for Responsive Politics. (2015). The Money Behind the Elections. Retrieved from www.opensecrets.org/bigpicture/.

Chang, H.-J. (2014). Economics: The User's Guide. London: Penguin Books.

Clark, G. L., Munnell, A. H., \& Orszag, J. M. (2006). The Oxford Handbook of Pensions and Retirement Income. Oxford: Oxford University Press.

Cruz-Martinez, G. (2015). Análisis Multidimensional del Estado de bienestar emergente y la pobreza en América Latina y el Caribe: Puerto Rico como estudio de caso. Universidad Complutense de Madrid. Retrieved from http://eprints.ucm.es/30004/

Cruz-Martinez, G. (2016). Welfare State Development, Individual Deprivations and Income Inequality: A Cross-Country Analysis in Latin America and the Caribbean. Social Indicators Research, 1-25. doi:10.1007/s11205-016-1465-4

Cruz-Martinez, G. (2017). Is there a Common Path that could have Conditioned the Degree of Welfare State Development in Latin America and the Caribbean? Bulletin of Latin American Research, n/a-n/a. doi:10.1111/blar.12556

Cruz-Martinez, G. (2018). "Revenue-Generating Potential of Taxation for Older-Age Social Pensions." Ageing International 43(4): 415-437.

Cruz-Martinez, G. (2019). Welfare and Social Protection in Contemporary Latin America. London: Routledge.

Danson, M., McAlpine, R., Spicker, P., \& Sullivan, W. (2012). The Case for Universalism. An assessment of the evidence on the effectiveness and efficiency of the universal welfare state. The Jimmy Reid Foundation.

Deacon, A., \& Bradshaw, J. (1983). Reserved for the poor. Oxford: Basil Blackwell and Martin Robertson.

Del Pino, Eloísa, \& Maria Josefa Rubio Lara (2016). Los Estados de Bienestar en la encrucijada: Políticas sociales en perspectiva comparada. Madrid: Tecnos.

Devereux, S., Masset, E., Sabates-Wheeler, R., Samson, M., te Lintelo, D., \& Rivas, A. (2015). Evaluating the Targeting Effectiveness of Social Transfers: A Literature Review. Institute for Development Studies Working Paper, 460.

Elmer, A. (1960). Folkpensioneringen i Sverige. Lund: CWK, Gleerup.

Esping-Andersen, G. (1990). The three worlds of Welfare Capitalism. Princeton, NJ: Princeton University Press.

Esping-Andersen, G. (1999). Social Foundations of Post Industrial Economies. New York: Oxford University Press.

Feenstra, R. C., Inklaar, R., \& Timmer, M. P. (2015). The Next Generation of the Penn World Table. American Economic Review, 105(10), 3150-3182.

Feldstein, M., \& Liebman, J. B. (2002). Social Security (Vol. 4). Amsterdam: NorthHolland, Elsevier.

Fiszbein, A., Kanbur, R., \& Yemtsov, R. (2013). Social protection, poverty and the post2015 agenda. Policy research working paper, 6469: 
http://econ.worldbank.org/external/default/main?pagePK=64165259\&theSitePK $=469382 \&$ piPK $=64165421 \&$ menu $P K=64166093 \&$ \&ntity $I D=000158349 \_201305$ 30132533.

Fiszbein, A., Kanbur, R., \& Yemtsov, R. (2014). Social Protection and Poverty Reduction: Global Patterns and Some Targets. World Development, 61, 167-177. doi:http://dx.doi.org/10.1016/j.worlddev.2014.04.010

Freeland, N. (2013). The Seven Deadly Myths of Social Protection. Pathways' Perspectives on Social Policy in International Development, 10.

Gilbert, N. (2000). Targeting Social Benefits: International Perspectives and Trends. New Jersey: Transaction Publishers.

Gilens, M. (1999). Why Americans hate welfare: Race, Media and the Politics of Antipoverty Policy. Chicago: University of Chicago Press.

Goodman, R., White, G., \& Kwon, H.-j. (1998). The east asian welfare model: welfare orientalism and the state. London: Routledge.

Gubrium, E. K., Pellissery, S., \& Lødemel, I. (2014). The Shame of It. Global Perspectives on anti-poverty policies. Bristol: Policy Press.

Gugushvili, D., \& Hirsch, D. (2014). Means-tested and universal approaches to poverty: international evidence and how the UK compares. CRSP Working Paper, 640.

Habibov, N. N., \& Fan, L. (2006). Social Assistance and the Challenges of Poverty and Inequality in Azerbaijan, a Low-Income Country in Transition. Journal of Sociology \& Social Welfare, 33(1), 203-226.

Heckman, J. (2012). Giving Kids a Fair Chance. Cambridge: MIT Press.

Heimo, L. (2019). Domestication of Global Policy Norms: Problematisation of the Conditional Cash Transfer Narrative. Welfare and Social Protection in Contemporary Latin America. G. Cruz-Martinez. London, Routledge.

HelpAge International. (2015a). Pension-Watch Database. http://www.pensionwatch.net/download/55129fc5749ec.

HelpAge International. (2015b). Pension watch. Social protection in older age. http://www.pension-watch.net/.

Huber, E., \& Niedzwiecki, S. (2015). Emerging Welfare States in Latin America and East Asia. In S. Leibfried, E. Huber, M. Lange, J. D. Levy, \& J. D. Stephens (Eds.), The Oxford Handbook of Transformations of the State. Oxford: Oxford University Press.

ILO. (2014a). More than 70 per cent of the world population lacks proper social protection. Geneva: ILO News: http://www.ilo.org/global/about-theilo/newsroom/news/WCMS 244748/lang--en/index.htm.

ILO. (2014b). World Social Protection Report 2014-15: Building economic recovery, inclusive development and social justice. Geneva: International Labour Office.

Kidd, S. (2015). The Political Economy of "Targeting" of Social Security Schemes. Pathways' Perspectives on Social Policy in International Development, 19.

Kidd, S. (2018). "Pro-poor or anti-poor? The World Bank and IMF's approach to social protection." CADTM, 13 April, Retrieved from: http://www.cadtm.org/Pro-pooror-anti-poor-The-World.

Kidd, S., \& Wylde, E. (2011). Targeting the Poorest: An assessment of the proxy means test methodology. Canberra: Australian Government AusAID. 
Klasen, S. \& Lange, S. (2015). "Accuracy and Poverty Impacts of Proxy Means-Tested Transfers: An Empirical Assessment for Bolivia," Courant Research Centre: Poverty, Equity and Growth - Discussion Papers 164, Courant Research Centre PEG.

Knox-Vydmanov, C. (2011). The price of income security in older age: Cost of a universal pension in 50 low and middle-income countries. Pension watch briefing series, 2, HelpAge International.

Knox-Vydmanov, C., Horn, D., \& Sevilla, A. (2016). The Philippine Social Pension at Four Years: Insights and Recommendations. Manila: Coalition of Services of the Elderly / HelpAge International.

Korpi, W., \& Palme, J. (1998). The Paradox of Redistribution and Strategies of Equality: Welfare State Institutions, Inequality, and Poverty in the Western Countries. American Sociological Review, 63(5), 661-687.

Kwon, H.-j., Mkandawire, T., \& Palme, J. (2009). Introduction: social policy and economic development in late industrializers. International Journal of Social Welfare, 18, S1-S11. doi:10.1111/j.1468-2397.2009.00635.x

Marshall, T. (1950). Citizenship and social class and other Essays. Cambridge: Cambridge University Press.

Midgley, J. (2014). Social Development: Theory \& Practice. London: SAGE.

Mishra, R. (1977). Society and Social Policy: Theories and Practice of Welfare. London: MacMillan.

Mkandawire, T. (2005). Targeting and Universalism in Poverty Reduction. Social Policy and Development Programme 23, , United Nations Research Institute for Social Development.

Molina, C. G. (2006). Universalismo básico: Una nueva política social para América Latina. Washington D.C: Banco Interamericano de Desarrollo / Editorial Planeta.

Mulligan, C. B., \& Sala-i-Martin, X. (1999). Social Security in Theory and Practice (II): Efficiency Theories, Narrative Theories, and Implications for Reform. NBER Working Paper, 7119: http://www.nber.org/papers/w7119.

Osorio Gonnet, C. (2018). "A Comparative Analysis of the Adoption of Conditional Cash Transfers Programs in Latin America." Journal of Comparative Policy Analysis: Research and Practice: 1-17.

Pierson, P. (2000). Increasing returns, Path-dependence and the Study of Politics. The American Political Science Review, 94(2), 251-267.

Rothstein, B. (1998). Just Institutions Matter. The Moral and Political Logic of the Universal Welfare State. UK: Cambridge University Press.

Rothstein, B. (2001). The universal welfare state as a social dilemma. Rationality and Society, 13(2), 213-233.

Rowntree, S. (1901). Poverty: A Study of Town Life. London: Longman.

Sánchez de Dios, M. (1993). El modelo sueco del Estado de bienestar. Revista de Estudios Políticos (Nueva Época), 59, 283-303.

Scarbrough, E. (2000). West European welfare states: The old politics of retrenchment. European Journal of Political Research, 38(2), 225-259.

Sen, A. (1995). The Political Economy of Targeting. In D. Van de Walle \& K. Nead (Eds.), Public Spending and the poor: theory and evidence. Baltimore: World Bank and The John Hopkins University. 
Sewell, W. H. (1996). Three temporalities: toward an eventful sociology. In T. J. McDonald (Ed.), The Historic turn in the human sciences. Michigan: University of Michigan Press.

Shen, C., \& Williamson, J. B. (2006). Does a Universal Non-Contributory Pension Scheme Make Sense for Rural China? Journal of Comparative Social Welfare, 22(2), 143-153.

SIPRI. (2015). SIPRI Military Expenditure Database. Stockholm International Peace Research Institute.

Sojo, C. (2009). Proceso político de la reforma social en América Latina: condiciones y recursos en torno a un "régimen" de universalismo básico. In C. Barba Solano, G. Ordoñez Barba, \& E. Valencia Lomelí (Eds.), Más allá de la pobreza: Regímenes de bienestar en Europa, Asia y América (pp. 371-399). Guadalajara: Universidad de Guadalajara, El Colegio de la Frontera Norte.

Stephens, J. D. (2002). European welfare state regimes: Configuration, outcomes, transformations. In E. Huber (Ed.), Models of capitalism: Lessons for Latin America. University Park: Pennsylvania State University Press.

The Heritage Foundation. (2015). Index of Economic Freedom. http://www.heritage.org/index/explore.

Thelen, K. (1999). Historical Institutionalism in Comparative Politics. Annual Review of Political Science, 2, 369-404.

Titmuss, R. M. (1976). Commitment to Welfare. London: Georges Allen \& Unwin.

UNPD. (2015). World Population Prospects: The 2015 Revision. http://esa.un.org/unpd/wpp/Download/Standard/Population/.

US Social Security Administration. (2015). Social Security Programs Throughout the World. https://www.ssa.gov/policy/docs/progdesc/ssptw/.

van Oorschot, W. (2002). Targeting welfare: on the functions and dysfunctions of meanstesting in social policy. In P. Townsend \& D. Gorden (Eds.), World Poverty: new policies to defeat an old enemy (pp. 171-193). Bristol: Policy Press.

Vijaya, R. M., Lahoti, R., \& Swaminathan, H. (2014). Moving from the Household to the Individual: Multidimensional Poverty Analysis. World Development, 59, 70-81. doi:http://dx.doi.org/10.1016/j.worlddev.2014.01.029

Willmore, L. (2007). Universal pensions for developing countries. World Development, 35(1), 24-51.

World Bank. (1994). Averting the Old Age Crisis. Oxford: Oxford University Press.

World Bank. (2001). World Development Report 2000/2001: Attacking Poverty. New York: Oxford University Press. 